ARTICLE

Received 10 Oct 2016 | Accepted 2 Mar 2017 | Published 30 Mar 2017

DOI: $10.1057 /$ palcomms.2017.22

\title{
The interno nell'interno: some furnishing paradigms for an interior as interiority
}

Imma Forino ${ }^{1}$

\begin{abstract}
This essay uses the Italian expression "l'interno nell'interno" to identify a specific case of the relationship between interior and interiority in the history of furnishing and interior design. From the Middle Ages to the twentieth century in Western culture various types of furniture locate a specific type of space-made of wood, curtains or masonrywithin a previous domestic space. These new spaces are often bound up with the desires for privacy, well-being and concentration. They permit people to withdraw into themselves, to have more intimacy, or engage in a privileged dialogue with others. To demonstrate this close relationship between interior and interiority this essay chooses three typologies of the "interno nell'interno": namely the studiolo, master bed and window. The first two are analysed as pieces of furniture, while the window is analysed as a space. The three typologies are selected for their special character as paradigms in the history of furnishing and interior design and their unique character as spaces of interiority. The essay analyses them by drawing on authors who write on the history of art, literature, philosophy, psychology, interiority, in addition to specialized texts on the history of interiors and architecture. In the conclusion, with the use of phenomenological and psychoanalytical approaches (especially Elvio Fachinelli's claustrophilic interiorisation), the essay demonstrates that these three models were true rooms of interiority in past ages. The studiolo, master bed and window can be considered mediums of inner development and wellbeing. The purpose of the essay is to show that the history of furnishing and of interior design can be understood and interpreted in accordance with values complementary to those commonly used, values that adopt an interdisciplinary approach and problematicity as a method of study, in order to shed light on the actual relationship between interior and interiority. Although this relationship was more evident in past ages, rather than in the present, the interpretational method adopted here is also offered as a possible key to studies of contemporary interiors. This article is published as part of a collection on interiorities.
\end{abstract}

\footnotetext{
${ }^{1}$ Politecnico di Milano, Milano, MI, Italy Correspondence: (e-mail: imma.forino@polimi.it)
} 


\section{Introduction}

rom the Middle Ages to the twentieth century in Western culture examples of furnishings can be found that have given rise to a new type of space within another interior. These are structures that, variously interpreted, are a constant in the history of interiors. In some cases the element of an additional border, which is physically distinct from its setting though included within it, appeared as early as the mid-fourteenth century. Through the design dynamics of the doubling and boxing of space, a second area is created within a larger space. Such a place, limited in its dimensions, is on a more human scale, can be arranged differently and is sometimes temporary or movable. This essay has defined this type of space as an interno nell'interno. ${ }^{1}$

The interno nell'interno has precursors and analogies throughout the history of architecture, if one considers its archetypal quality as an "enclosure" "double shell". Though it has different morphogeneses as well as different purposes, a constant feature is the presence of one inhabitable space, whether enclosed or open-air, within another.

This essay shows how some types of furnishings or recessesstudiolo, bed or window-which have become established as micro-environments over time, can be considered spatial and inhabitable paradigms of the phenomenology of an interno nell'interno. On the other hand, in addition to being physical structures, they identify a psychological space well suited to cultivating interiority: they enclose intimacy within intimacy, with the need to withdraw into a refuge or to build a space of one's own being given a material form. The essay uses phenomenological and psychoanalytical approaches (especially Elvio Fachinelli's claustrophilic interiorisation) to explain that furnishings can be considered as a medium of inner development and well-being or a sort of material artifice between the individual and the world, between the desire for a privileged or representative personal space and whatever surrounds it.

\section{From furniture for studying in to private refuge}

Concentration, meditation, self-exploration, temporary distance from the world: extolled by Petrarch in a famous text of humanistic culture (De Vita solitaria, Petrarch, 1346-66) and later taken up by Leonardo Da Vinci, ${ }^{5}$ solitudo [solitude] distinguishes the work of the scholar and is reflected in the search for an appropriate space: it is an intimate shell in which one can cultivate one's development and creative work, as well as being a psychic container for the construction of interiority, in which solitude can emerge as a constructive affirmation of the self.

Before the studiolo became an elitist private space in the Renaissance palace, the study was a piece of furniture. Its evolution-from an inhabitable piece of furniture used for writing and reading to an architectural space for study and gathering collections ${ }^{6}$ - symbolises the process of reclaiming the self in cultural terms, as well as the historical transition to secular and anthropocentric knowledge after centuries of ecclesiastical rule. In the pre-medieval age, the individual organization of the copying and illumination of sacred texts made use of a combination of different elements arranged within the aula scriptoria (or scriptorium) of the monastery: a stool to sit on, a footrest to raise one's feet off the cold floor, a surface upon which to place the manuscript to be illuminated, an armario [cabinet] serving as an archive. These pieces of wooden furniture were of simple workmanship: surrounding the coenobite or scribe absorbed in drawing images, they characterised the desire to set up a microcosm suited to the work. The subsequent adoption of a lectern joined to the footrest, and perhaps to a chair equipped with arms, further shaped the earliest idea of a study nook or cabinet. This is epitomised in the panel of Saint Jerome in the
Study (c. 1475$)^{7}$ by Antonello da Messina. ${ }^{8}$ The wooden platform raises the figure of the Father of the Church off the floor and functions as desk, bookcase and archive, circumscribing the man intent on reading. The image of the furniture immersed in the void of the cathedral may seem unreal, but is actually an idealised depiction-with the front wall and ceiling removed for pictorial reasons - of a structure really in use between the late fourteenth century and the early fifteenth: wooden boxes, fitted with doors and windows, with built-in descho [desk], drawers, bench and bookcase. These were elements arranged in the interior of vast palace rooms, into which the scholar withdrew to find intimacy and warmth. Such a study-box was created around 1451 by a certain Baldassera for Lorenzo Dolfin, ${ }^{9}$ while an inventory (1498) of the household goods of Lorenzo de Pierfrancesco de' Medici in Fiesole mentions a similar container, in the form of a box or closet. ${ }^{10}$

While the architect was entrusted to work on the structure and final details of a building, other specialists-carpenters, upholsterers, decorators and painters-were in charge of furnishing its interior: this inhabitable furniture for studying was tailor-made and, although made up of light materials, was mainly fixed. On the other hand, its functional simplicity recalled the monastic cells of monasteries, fitted with built-in furnishings of masonry doors, recesses and shelves, as seen at the Certosa di Pavia (since 1396) or as shown in the pictorial cycle of the Dominican Order by Tommaso da Modena in the chapterhouse of San Nicolò in Treviso (c. 1352).

In the Early Renaissance study furniture was made up of a solid desk or descho da scrivere [writing desk] with a sloping or horizontal surface. In the latter case, another surface with an adjustable slant (from 15 to 70 degrees) would be placed above it for reading or writing on. The solid vertical supports were fixed and equipped with compartments, cabinets and drawers. The chair, set first on three and then four supports with a hard back and arms, in some cases revolving on a pivot, accompanied the "box desk" (Thornton, 1991: 229) or "furniture refuge" (Giedion, 1948: 281). In other models, the descho surface was designed with two heights: the lower one for working on and the higher one to conceal the writer from view; shelves and drawers made good the difference between the two levels. In the Apparition of the Holy Spirit to Saint Augustine $(1438)^{11}$ by Filippo Lippi, this piece of furniture is depicted as a wooden cell inscribing the saint absorbed in writing.

The Biblioteca Laurenziana (Florence) contains actual examples of such objects. Intended for a limited and qualified circle of scholars, the long reading room was laid out with identical rows of plutei, ${ }^{12}$ furnishings designed by Michelangelo in 1524 and set close to the fixed placement of the manuscripts: the reader had to search for the chosen book at the desk where it was stored and sit there to read it. In form and decoration, these pieces recalled the prie-dieu of the previous century, illustrated in the Annunciations of Carlo Crivelli and Filippo Lippi. In fact, the pluteus arose out of the combination of the prayer-stool, the church pew and the descho for writing raised on a platform. It was made up of a high, deep parallelepiped that on one side became the backrest of the bench attached to it, and on the other a support for the bookshelf and the sloping surface above, which served as a lectern. The central element completely isolated the scholar from those in front of and behind him in the rows of benches: "enclosed by the high sides of the bench, Michelangelo imagined the reader protected by an enveloping space, visibly and psychologically isolated from the rest of the room, in intimate conversation with the texts laid firmly on the sloping surface" (Portoghesi, 1964: 315).

Such a refuge appeared again in the fifteenth-century illuminated manuscripts portraying Petrarch or other scholars at work. Within the complex historiated initials, the human figure 
seems to be enveloped in a wooden sheath, which is bent to form a platform, writing desk, bench and shelves. The images recalled a richly decorated, enclosed and secluded place figuratively depicting the most private space of the palace: the studiolo. According to Leon Battista Alberti's precise instructions in the third volume of his Libri della Famiglia (1432-34), it was the most secret room in the building, inaccessible even to one's wife, where the master of the house kept documents relating to his business, in addition to literary works. "Within the architectural complex, the study reshapes the figure of a man who has adhered, despite the inevitable mediation, to the ideal of the vita solitaria [solitary life]: far from the public areas of the home, scarcely visible from the outside, reachable with difficulty even by others in the home and often on one of the higher floors" (Franzoni, 1984: 307).

Generally situated beyond a room and antechamber, and at times connected to a reception room, the studiolo would be small $(4 \times 3.5 \mathrm{~m}$ or even less), covered by barrel or coffer vaults and might be furnished with a lettuccio or daybed, a type of sofa with a high seatback and arms for resting or recovering from the turmoil of the day. Richly patterned, this space represented the cradle of lay power, with its passion for the arts and devotion to the study of the humanities. It expressed the close ties between power, wealth and culture, while the decorative furnishing, mainly depicting mythological themes, arose above literal iconographic significance to a moral value-as well as the recovery and study of classical antiquity -through allegorical transfiguration.

The late-fifteenth-century studiolo of Piero de' Medici in the Palazzo Medici, with decorations on the ceiling and floor by Luca della Robbia, that of Lionello d'Este in the small palace of Belfiore in Ferrara, enriched by a series of paintings depicting the nine muses, the sixteenth-century study (later dismantled) of Alfonso I d'Este in the Palazzo Ducale in Ferrara, or the other (the camerino d'alabastro) with paintings and marble reliefs, also in Ferrara, and Vespasiano Gonzaga's small Camerino di Enea (1585) in the Palazzo del Giardino in Sabbioneta are only some examples of a place considered indispensable when designing a residence during the Renaissance and for the sense of personal concentration that could be attained within it. The studiolo was in fact considered a "place of the soul", where "interiority is devoted to reflection and study: outside one moves amid concrete and tangible though mediocre certainties; but within the walls of the study everything is called into question and one searches the authors and great models for confirmation or refutation; doubt is a welcome guide, making it possible to reach new and fertile shores" (Sozzi, 2011: 102).

Federico da Montefeltro's studies in the Palazzo Ducale in Urbino and in Gubbio (both completed between 1473 and 1478), the two studiolî of Isabella d'Este in Mantua ${ }^{14}$ and that of Francesco I in the Palazzo Vecchio in Florence (1570) bear witness, through the richness of their decorations, to the care with which these rooms were created, where the whole setting seems to envelop its inhabitant because of the use of wooden panelling with intarsia decorations (which often concealed containers) or paintings (usually collections of framed paintings), which modifies the physical perception of the architectural space. While the artificial atmosphere of the study in Urbino celebrated the humanistic ideal of meditation rather than Federico's passionate zeal for study, and the later one in Gubbio, featuring even more extraordinary intarsia decorations, was an 'astonishing triumph of "still life" and of abstract decoration' (Chastel, 1959: 378), the studies of the House of Este marked the cultural passage straddling the two centuries, arising from Isabella's new antiquarian interests. Work on the Florentine study of Francesco I, directed by Giorgio Vasari to an iconographic project by Vincenzo Borghini, formed the mature example of a style which then began to go out of use. The receptacle in the form of a chest (also known as a cassone), with a curved lid, ${ }^{15}$ because of its coffered barrel-vaulted cover, mirrored above all its owner's obsession with cataloguing: here corals, quartz crystals, metals and chemical substances found a home, instead of books and papers. ${ }^{16}$

While in later ages furniture for writing became specialised in the type of the secrétaire in France, the trumeau in Italy and the writing cabinet in England, it was in the late nineteenth century that it was once again shaped like the "nook" of Renaissance legacy, reverting to its formal stylistic features and methods of archiving documents. The Wooton Cabinet Office Desk (1874), manufactured in the United States for about 20 years, was an expensive piece of furniture destined for prestigious offices. Designed in various styles, it opened up with two or more deep doors, equipped with shelves, compartments and drawers, and had a pull-out or folding writing desk. ${ }^{17}$ It recalled the travel chests for clothes and, at the same time, the medieval armari, while the decorations were styled with neo-Renaissance features. It was a "miniature counting house" (from its advertising) that enclosed the book-keeper and isolated him from the rest of the room. Its 60 or 100 compartments allowed storage of a great quantity of documents, rolled up and bound with a ribbon as was done during the Renaissance. However, a particularly sharp mind was necessary to remember exactly where each was stored. ${ }^{18}$

At the turn of the century, the interior nook of the study was turned into an instrument for the efficient production of tertiary work, indicating how far the handling of information was already prevailing over the individual's creative ability. The Workskull (2005) by Atelier Van Lieshout could be considered a contemporary exception: a scholar can study or read inside an inhabitable green "skull" (in moulded plastic) in a garden, courtyard or house.

\section{From social microcosm to symbol of power}

In the history of furniture the bed was among the earliest pieces to acquire a form of its own in ancient times, but it was only at a certain point that its development can be seen as "an independent micro-architecture, whose dimensions can be considered a basic unit, the modular unit around which the whole home [or the whole room] was constructed and which is indispensable" (Baroni, 1983: 314).

In the medieval home, characterized by an absence of distinct spaces and functions, the bed was made up of a wooden frame or a pair of trestles and a panel made of boards set together, varying in width from 1.60 to 3.50 metres. As a rule it would be occupied by the married couple with their younger and older children, as well as brothers and sisters, or even strangers who needed to share the room. In the upper classes it was more common for servants or housemaids to lie down together with the lord and lady to protect their masters' sleep. Such promiscuity in sleeping habits mirrored a semi-nomadic lifestyle, with temporary arrangements or furnishings that could be dismantled and were convenient when moving from castle to castle, as well as a domestic community in which conviviality and cohabitation were the rule. ${ }^{19}$

In the late fourteenth century, a more conscious design of the home and its spaces, in addition to greater self-awareness, caused sleeping to become "ever more confined behind the scenes of the human community" (Elias, 1936: 301). Furthermore, the Christian view of sex, backed by a new awareness of hygiene, supported the idea of sleeping in separate rooms and beds. The married couple required more intimacy: privatisation of the marriage imposed isolation and "intimacy of the bed came before the separate room" (Mumford, 1938: 30). The addition of a headboard, curtains and chests surrounding it gave the bed a monumental character, made even more conspicuous if it was placed in the centre of the room away from the corners. Its furnishings increasingly structured it as a separate pavilion, a small independent setting within the bedroom, so as to finally become a 
miniature version of the dwelling itself. Not only did its formal appearance change, but also the relation between the furniture and its inhabitants: the bed became a protective and private space, encouraging love-making, undisturbed rest and daydreaming. The idea of borders, of enclosure, of secrets emerged in the house. It was a gradual evolution that found a representative image in some definite types: the bed with independent curtains, the wardrobe bed, the "architectural bed". 20

In the first type, the marriage bed was surrounded by curtains hanging from hooks on the ceiling, the walls or suspended using rings sliding on a slender wooden or iron frame attached to the ceiling of the room. The curtains were far enough from the mattress to provide space to move around freely. Such a "fabric box" was of a lighter texture in summer and heavier in winter (the curtains being removable and replaceable), and could open up partly or completely to the surrounding space. The frequent presence of chests around the bed further marked it as a clearly defined and isolated object, as depicted by Fra Angelico in his Healing of the Deacon Giustiniano (1443). ${ }^{21}$

Beds with independent curtains became popular during the Renaissance, later growing more complex, with cone-shaped or domed coverings and hanging canopies of increasingly elaborate shapes, so that four small columns were necessary to support the heavy drapery and the higher fabric cover (four-poster bed). In the following centuries, the bed evolved into models with covers, à la duchesse or d'ange (with two small front columns and a tall headboard to support the canopy, in Louis XIV style), à la romaine (a bed next to the wall with two headboards or chevets) and à la polonaise (with a small cupola supported by iron S-shaped elements, Louis XV style), with a tambour canopy, à la imperial (with a flying canopy) or with a half canopy (in the nineteenth century). In Imperial Style or Neo-Renaissance beds, the arrangement of curtains and folds was so complex that the bed was turned into a "room within a room" as a sort of fabric cocoon. It was only towards the end of the nineteenth century, above all in middle-class flats, that the bed with curtains was almost completely abolished, as the entire room was transformed into a protective shell.

The wardrobe bed was increasingly configured as a true microroom within another chamber: it was a wooden parallelepiped that, in addition to the bed, contained a further part of space. It is likely to have derived from the Breton popular tradition of beds: a wooden piece of furniture, raised off the floor by feet with a high base, containing the mattress and closed from within by a sliding panel. It was a sort of "small private apartment: once inside, with the doors closed, one was at home" (Perrot, 2009: 62). In Italy, it was mainly recessed into the wall but, if it protruded into the room, it looked like a chest. Popular north of the Alps and in rural areas, it was fairly uncomfortable, suffocating and unhygienic, because it did not allow the air to circulate easily.

A refined and more practical evolution of this "sleeping wardrobe" is a marvellous example of refined cabinet-making: the alcove of Federico da Montefeltro in the Palazzo Ducale in Urbino. $^{22}$ The external decoration of this wooden construction included some typical architectural elements (base, pilasters, entablature) together with varnished and decorated panels (the ducal coat of arms at the front and trees and animals on the sides). The interior alternated low wooden panels with gold decorations. A true "room within a room" with an independent grandiose façade, Federico's sleeping box, while adopting the proportions and stylistic features of the great Renaissance chambers, at the same time developed a variation on the scale. If the latter responded to the practical needs for both protection against the harsh climate and greater privacy, it also made the bed independent of its surroundings: it was a refuge that "derived its form from its function and only secondarily allowed its user to enter" (Arnheim, 1977: 168-169). On the other hand, the stereometric form of Federico's alcove recalled the abstract pursuit of "order, law, discipline against the immeasurable, the infinite and the dispersion of Gothic spaces and the haphazardness of the Romanesque" (Zevi, 1948: 76), which was the basis of architecture in the fifteenth century. In this century, even furniture became an instrument of measurement and of "man's intellectual control over architectural space" (Ibid.: 78). Nor can one ignore the representative value that this imposing piece possessed in relation to the austere forms of the Renaissance palace. In this age, the bedchamber started to become the very centre of the house, not just a place for reposing, but also for conversing with friends, and sometimes even holding receptions, while the bed itself acquired something of the function of a throne dominating the room.

The architectural bed included some of the functional elements of the bed with curtains and the wardrobe bed, but formally it was configured as a micro-architecture. It drew on the vertical elements made necessary at a certain point by the curtains' weight, as well as the sense of a definite nucleus; but from the sixteenth century on, its parts-pillars, platform, covering-were treated in the same manner as any other architectural elements. The supports thus became robust carved pillars, columns with pedestals and ornate capitals or even took on the form of herms. The fabric canopy was replaced with a heavy wooden entablature, sometimes with capitals in different styles. Curtains, if added, were attached below the frames and grazed the floor, and the platform was fitted flush so as not to interfere with the curtains. Sodoma's fresco of The Marriage of Alexander and Roxane (1519), at Villa Farnesina in Rome, exquisitely illustrates this rich architectural piece. In fact, for the very first time, architects, and not carpenters or upholsterers, designed this type of bed. "We can imagine that architects were often involved in designing more lavish, expensive beds as well as the fundamental elements of furniture in a manor house, which required on the part of the designer a knowledge of architectural rules and the appropriate lexis" (Burns, 2001: 151). The success of this type of bed abroad, as well as in Italy, was noteworthy: it was almost an altar with its overhanging canopy. ${ }^{23}$

In the seventeenth- and eighteenth-centuries, receiving guests in the bedchamber became a widespread custom for those who adopted the aristocratic lifestyle. The bed was placed in the centre of the room with the headboard close to the wall in order to have equal space at each of the longer sides. The bed's monumental character was emphasized when it was set on a raised parquet floor and surrounded by a balustrade to prevent anyone, except those of the highest classes, from approaching too closely. This is the case of the lit de parade [state bed] with its "powerful symbolic value, as it reflected the upper-class position of the owner or his hope that an equally upper-class person would come into view and would sleep in that bed" (Thornton, 1984: 19). At Versailles, even more than by the throne, the grandeur of the king was represented by the royal bed with a canopy, separated by a balustrade from the rest of the state bedchamber, where no one was permitted to sit. Here the Sun King received ambassadors and special messengers, while his real bedroom was behind the scenes of the state bedchamber. In the chambre de parade [state bedchamber] the bed became one of the supreme symbols of power, with an almost religious value: "As within a church, where the enclosure of the chancel separated the altar from the faithful, also the balustrade defined a sort of tabernacle. It isolated the king's bed. That bed, covered in rich damask and equipped with heavy curtains, was guarded day and night by valets" (Perrot, 2009: 39). The structure of the room and the furniture amplified the ritual of devotion to the sovereign-the daily ceremony of Lever and Coucher-attended only by privileged courtiers. In the state bedchamber, the bed was "the altar where the 
transubstantiation of the physical body [of the King] into a mystical body took place" (Ibid.: 40).

The interno nell'interno-consisting of the combination of the bed and the independent casing, which enhanced the bed while isolating it even more-returned in the following century's furniture, above all in the intentional recovery of the idea of classicism, though in different forms. For example, the Empire Style designs of Charles Percier and Pierre François Léonard Fontaine, published in their Recueil de Décorations Intérieures (1801), which presented beds designed as micro-architectures; or Ferdinand II's bedroom in the Palazzo Reale of Caserta, with a canopy supported by four lances, which was independent of the marriage bed, a mahogany lit-en-bateau. ${ }^{24}$

In the late nineteenth century, the bedroom was standardised to more modest proportions. In middle-class homes, the bed furniture was a secret alcove, but functional for reproduction. Only the married couple, in the intimacy of their bedroom, were allowed to procreate, standing as a social model: at that time, "sex was not only judged, but also regulated" (Foucault, 1976: 26). The bed became lower, smaller and more domesticated, mirroring a family model that emphasised the feminine virtue of maternity and a sexuality forced to "set up house" (Ibid.: 9). The closed parallelepiped that, in addition to the bed, encloses a further space, seems to have returned in a prototype by the brothers Ronan and Erwan Bouroullec. The bed Cabane (2001) is a limited edition for Kreo Galerie (Paris), but the two designers see it not as an inhabitable object, but only an experiment in an idea of border (Bouroullec and Bouroullec, 2003: 170).

\section{From a place for dialogue to a machine of the objective glance}

A window is not just an opening in the wall to let in light and air, but it "can be a private room within a room" (Kahn, 1973: 137), not merely an "optical apparatus" of the architecture (Teyssot, 2013: 254). In medieval homes the window, more than the bed, became the alcove allowing one to withdraw, alone or in intimate conversation (as at Hedingham Castle, Essex, c. 1140, or at Castel del Monte, Italy, c. 1240): the window was the first spatial conquest of intimacy. ${ }^{25}$ Taking advantage of the depth of the wall, it was made an inhabitable space: initially with the embrasure splayed so as to offer a place to sit, perhaps equipped with cushions; then with the addition of small parallel wooden or stone benches. In the Renaissance palace, the window embrasure again became a privileged place to linger, but it was above all the ideal place for reading, favoured by the light entering the room. Sometimes its depth accommodated a small fabric upholstered bench and a writing desk, while the sides were used as recesses to place books: it was a miniature study that could be closed with double curtains. In the eighteenth century the addition of one or two large mirrors along the splays made it brighter, in addition to shedding more light in the farther reaches of the room it opened onto.

In German and Scandinavian middle-class homes, in the nineteenth century it became a regular practice to place a platform in the window embrasure, thus creating a characteristic viewing place, allowing one to look out at the street from above, hidden by the curtains on the windowpane. The wooden platform was always accompanied by one or two chairs or cushioned benches; sometimes a wide curtain defined it more clearly as an independent little space, as illustrated by Johann Erdmann Hummel's watercolour, Sitting Room in Berlin (c. 1820-1825). ${ }^{26}$ The window embrasure was therefore a place where a dialogue developed between the protective domestic space and the amazed projection into the external world. "The home gives the man who dreams behind the window $[\ldots]$ the sensation of an outside, all the more different from the interior, the greater the intimacy within the room. The dialectic of intimacy and the Universe seems to become more definite thanks to the impressions of the hidden being who sees the world within the window frame" (Bachelard, 1948: 106).

In the early nineteenth century, the window also became a pictorial theme of great interest, which allowed a view of the interior transpositions imagined by Romantic artists as well as the organisation of those small spaces. Georg Friedrich Kersting was one of the painters most interested in the window embrasure, where he set the stories of men and women intent on writing, reading and sewing. A small table, a writing desk and a chair accompanied their daily work illuminated by the glimmer of light shed from above, leaving the rest of the room in shadow. The activity of these figures, often sitting with their back to the viewer, was concentrated underneath the light, but Kersting's intention was to communicate above all "the sense of the interior, of the 'apartment' in the fullest sense of the world-therefore the characters turned their faces in the opposite direction: they were really detached from every external thing, isolated, absorbed in the Gemülichkeit, in the Stimmung of their personal shell" (Praz, 1964: 204). The German painter's interiors emanate an "idyllic order in opposition to external chaos" (Rewald, 2011: 10): within, a type of austere life is reflected; the furnishing is in the simple and solid Biedermeier Style. ${ }^{27}$ The light softly bathes the people busy at detailed work, illustrating the domestic interiority of a quiet life passed at the window.

One architectural development of the window opening was the erker, a slight glazed projection, on one or two levels, which broadened the inhabitable space and structured the building façade. It became popular in the late-Gothic period, above all in Northern Europe, where the interior tended to swell outward with small covered loggias and belvederes. An additional spatial extension was the bay window (with a rectangular or polygonal plan) or bow window (with a semi-circular plan), a glazed or covered avant-corps, initially located only on the ground floor of the home, creating a direct relationship with the outside. Typical of the traditional English house, it formed an extension to the room and was furnished with comfortable seats and tables, where several people could sit talking, withdraw into smaller intimate groups and admire the panorama. In Victorian houses, this responded to the desire to have areas with more or less privacy within a single room, undisturbed by people passing by. This entailed an unbalanced plan of the building, which was projected, albeit marginally, towards the outside, thus reinterpreting the motifs of the loggia, the terrace and the bow window of ancient origins: all authentic "rooms within rooms".

As long as the building's load-bearing walls had to be thick, the window embrasure was one of those small spaces that architects worked to make more comfortable. Yet, even when construction methods allowed for the use of lighter curtain walls, furnishings with surprising designs and false ceilings were sometimes provided so as to regain a type of spatiality that was no longer structurally necessary, but whose sense of intimacy and privacy were still considered indispensable. In domestic culture the watershed was the adoption of ribbon windows, as warmly advocated by Rationalist architects. With Le Corbusier and Pierre Jeannaret the window essentially became a machine to capture light according to pictorial intentions: "the light is 'applied' to architecture as an external factor" (Cusano, 1979: 55). Hence the window became a precision instrument enhancing the purity of the architectural volumes while "eloquently cutting out" selected panoramic geometries. $^{28}$

Controversially in conflict with his predecessors-who supported the vertical window and abhorred the "perpetual panorama", to which the ribbon type unavoidably condemned the inhabitants ${ }^{29}$ - Le Corbusier maintained the importance of securing as much light as possible, as measured at eye level, which 
could be guaranteed by the new window. The vertical window, with the three-dimensional depth of its microcosm, was anthropometrically measured and brought the human figure back to the centre of the traditional cultural topos mentioned in this essay. The sight of the person who inhabited such a space roamed freely from the sky to the ground, thus allowing a choice of different viewpoints: "I wanted a narrow window, because the smaller the window, the farther and better the eye of the house sees" (Bachelard, 1970: 99). On the contrary, Le Corbusier's window programmatically manipulated the human eye: the glance was "horizontal", in an attempt to establish an "objective" relationship with the outside that was actually designed by the architect beforehand.

The strip window diminishes ... the perception and evaluation of the real depth of the landscape in view. This effect is even amplified by the extreme separation of its vertical limits [...], as the window escapes the visual pyramid and therefore the simultaneous apperception by the viewer, so that the perceived loses its connotations of a view framed by the window (Reichlin, 1988: 71).

Therefore, the ribbon window contradicts the prospect created by the deep splays and the traditional window's framing of the view, almost flattening it into a two-dimensional surface and favouring enforced objectivity instead of the personal interpretation of the gaze:

Le site 'est là', with its looming presence, as if it were glued to the window casing, both because the detached and reassuring view of the whole is precluded, and because the depth perception is greatly diminished as the transition between closer and familiar objects and those further away remains hidden from view. (Ibid.: 72).

In houses, the adoption of the Rationalist window, flat and with a fixed perspective, put an end to the intimacy of the window embrasure as a satellite space attached to the room: it meant the sacrifice of semi-darkness as well as the intermediate spaceneither interior nor exterior-of quiet and security, of a "room within a room".

The underground but progressive crumbling away of that microcosm, with the changes it brought about in the experiences and customs of living [was brought about] at the hands of Le Corbusier [...] The strip window breaks the 'case of private man' and the external world bursts into the 'intérieur '. [...] No longer contained by walls, curtains and drapery, the light pours in from that fissure and weakens space and objects, bringing 'sentiment-objects' back to their original, solid and uninspired use as 'instruments' (Ibid.).

Though detached, the "immersing" power of the protagonist's glance in one of E.T.A. Hoffmann's last stories (Des Vetters Eckfenster, 1822) is now lost. ${ }^{30}$ The view of modern man changes: from being an actor he becomes the audience. And the way he inhabits the house likewise changes now it is deprived of intimate refuges and clearly illuminated in every corner.

\section{Conclusion: the interior room, or the interior as interiority}

Furnishings that capture the void, recesses that contain a person: the doubling or inclusion of space, are all parameters through which different ways of inhabiting the house can be organised. Taken as paradigms of the domestic microcosm, the examples described bring about a series of critical interpretations regarding the theme of inhabiting interiority, if analysed in accordance with the phenomenological approach.

The architecture of a room is profoundly influenced by the "architecture" of the body and the human experience. A room is an interior and "interiority" [...] is an ongoing human experience. We seem to live inside our bodies, to observe the world through our eyes. Looking at an actual room, we see a reflection of this ongoing human experience of interiority [...] When we think about architectural space from a phenomenological point of view, ordinary elements such as doors and windows become much more than functional objects; they become symbols of the human experience, of our isolation within our bodies and of our freedom to explore the world, of our introversion and extroversion. (Davies, 2011: 106-107) ${ }^{31}$

The inner bedroom, which requires the utmost values of intimacy, pursues the protohistoric motives for wellbeing and, among these, the euphemisation of the symbols of "swallowing" and of "being swallowed", of which the myth of Jonah in the belly of the "great fish" is one the most emblematic archetypes, analysed by the philosopher Gaston Bachelard in relation to the home. ${ }^{32}$ Being "swallowed" or "being contained" does not deprive the subject of value; on the contrary, it is made a participant in the relativisation of the terms container and content: the swallower can in turn be swallowed, the content can in turn be a container. According to Bachelard, the interior immensity needs to be contained to be in its element, to therefore turn to a "phenomenology of the cavity" or to curl itself up as in a womb. The particular sphere of a secluded place, for which the rest of the house can only provide a frame of reference, therefore requires an "enclosure" clearly configured as an "independent place". The image of enclosed security seems to be confirmed by the so-called process of gulliverisation-explored by Bachelard and Gilbert Durand ${ }^{33}$ - which starts "always from a fantasy of swallowing [...] joined with the phantoms of protective interiority" (Durand, 1963: 213). In our case, the 'Lilliputian reverie' takes shape through the miniaturisation of spaces into which one withdraws, as also underlined by Leonardo da Vinci: le stanze ovvero abitazioni piccolo [...] ravviano lo ingegno, e le grandi lo sviano. ${ }^{34}$

The person who is "happy in a small space, achieves an experience of topophilia", wrote Bachelard (1957: 172). In these small interiors, an apparently contradictory perspective relativises the dialectic of the content and the container, since-and this is not a paradox - "the inside of a small object is large" (Ibid. 1948: 22 ); or, in other words, the content (interior immensity) is vaster than its container. It is fragmentation of volumes and constriction of spaces that enclose intimacy within intimacy like concentric circles in a place, such as the domestic one, predestined in and of itself for that purpose (at least in Western culture until the twentieth century). This is sometimes obtained through the device of boxing or doubling of the interior: as in a set of Chinese boxes or Russian dolls, nested one inside the other, a space of smaller dimensions is created within another space and included within the first. At other times the miniaturization of the secluded space requires it to be set within a niche, a receptacle, a residual space, modified just enough to make it inhabitable.

To illustrate the point, this essay has examined two different phenomenological situations of furnishing throughout the centuries: one is the concept of a cabinet or a piece of furniture that is turned into a space (like the furnishings of the study or the bed); the other is a place that becomes a container for the individual (like the studiolo or the window embrasure). In both cases these are "anthropocentric caskets", furnishings or small spaces designed "on a human scale" that enhance individuality. The other interpretation, which formalises and takes on the 
symbolic and psychological aspect of inhabiting interiority within the domestic space, is that of the claustrum [enclosed place] or of the experience of claustrophilia according to Elvio Fachinelli's interpretation. ${ }^{35}$ The latter, very different from the unconscious memory of prenatal experience, was defined by the psychoanalyst as follows:

I decided to coin this new term to underline the intensity and the strength of the impulse towards claustrum, enclosure. Compared to this impulse, the apparently symmetrical and opposite situation, claustrophobia, appeared to me an accident along the individual's path, something that was always included, at least in part, an essential part, within the area of claustrophilia. The term, agoraphobia, already available and in appearance similar, seemed inappropriate, as it implied first and foremost a 'fear of openness', while I was more interested in underlining the 'need for enclosed places'. I also want to emphasise that this enclosure, this claustrum, indicates-but only in the last resort-an enclosed place linked to the model and image of the mother's womb. I believe it primarily refers rather to the act of enclosing oneself, of locking oneself inside. And this matches the word's etymology. The Latin term claustrum means key, lock, bolt, etc.; it was only much later that it took on the meaning of an enclosed place (Fachinelli, 1982: 62-64).

The circumscribability of the interior relativises the position of the human figure in the space and gives it a new inner centre. Transcending the strict rule of the geometric form as regards 'inhabited space ${ }^{36}$ and taking on an image that was so highly valued by Benjamin (1982: 290), this essay can hardly help considering the paradigms discussed (studiolo, bed and window) as 'containers for man' or 'cases' in which man settles with his things; or-to paraphrase an image of Bachelard (1957: 106) - as "jewellery boxes", items that from being precious 'prisons for objects' have become coffers for man and his need for intimacy.

If the desire to withdraw and enclose oneself follows the rêverie of envelopment and gulliverisation, the theme of claustrophilic interiorisation seems to coincide with that of the favoured locus, while the phenomenology of the cavity cannot do without the container-content dialectic, which can be manifested through furnishing, on different dimensional scales. In this respect child psychology proves revealing: after the prenatal experience and that of the mother-infant feeding relationship, children consider the home as the centre of their individual world, a reassuring known in opposition to the unknown and threatening reality that seems to surround them. At times, not having a place of their own to take refuge in, a table or a chair used as a hut helps them find a sense of security through the creation of a miniaturised place, which is associated with a feeling of belonging. On the other hand, inclusion is one of the elementary topological intuitionswhich in the third dimension is represented by an object contained in a closed box-through which the child understands space, though unable to represent it three-dimensionally.37

An apparently lost interior image then seems to underpin the phenomenology of the interno nellinterno. Considering it in its abstraction, it appears as a claustrophilic space par excellence, an ideal that finds a possible concreteness when individuality expresses, through furnishing, its desire to barricade or nestle itself in a refuge, an enclosed place that is suitable for the "joys of envelopment". If this is configured in the unconscious as a reduced world, the spatial devices of inclusion or doubling make it an intimate casket, which physically and psychologically isolates its inhabitant from the rest of the house. The interno nell'interno corresponds to a phenomenology of dwelling that makes furnishing a medium of inner development and wellbeing. It is a material artifice-perhaps comparable to a transitional objectbetween the individual and the world, the desire for a privileged personal space and whatever surrounds it. In such a case, "the space becomes something more than a mere mirror of the soul; it is rather a strengthening of the soul, or, if we choose to continue with the image of the mirror, an interplay of reflections, opening up endless prospects; a profundity of multiplied identical reflections" (Praz, 1964: 22). In the interno nell'interno, these reflected prospects take shape, and interiority seems to be capable of inhabiting this interplay of reflections, if not fully, then at least in the illusion of the cabinets and recesses constructed over the past centuries. $^{38}$

\section{Notes}

1 For a complete and detailed definition of the interno nell'interno, also related to nondomestic environments, see Forino (2001).

2 As for the idea of architecture as enclosure, see Semper (1879-1889: 117-118) and Semper (1851: 207-208). Furthermore, cf. Di Domenico (1998).

3 Semper (1851: 222), mentioned "a unique box-styled principle" related to the royal fortress of the Assisi where the "units, different in their size though homogeneous in their form, close up and are reunited in larger units of the same kind".

4 Cf. Venturi (1966: 86-104), who reported a number of examples of double-shell structures repeatedly framed or stratified, from several historical periods. On the "double enclosure" in historical and contemporary architecture, see also Forino (2016a: 58-65)

5 Cf. Solmi (1910: 5).

6 It should be pointed out that furnishings specifically designed for writing and reading as well as the architectural space of the study are both referred to as studiolo. Cf. Battisti (1962: 184-189) and Liebenwein (1977: 1).

7 Oil on wood panel, National Gallery, London.

8 An enlarged description of the panel of Antonello is in Forino (2001: 23).

9 Cf. Thornton, 1997: 53 and 207.

10 Ibid: 54 , no 5 .

11 Tempera on wood panel, predella of Barbadori Altar-piece, Galleria degli Uffizi, Florence.

12 The term pluteus also indicates the bronze or fret-worked marble parapet, generally separating the altar area from the central nave of a church. The Latin origin of the term pluteus has a military connotation and means "refuge".

13 Cf. Alberti 1432-1434: 219.

14 The first studiolo situated in the north-east tower of the San Giorgio Castle in Mantua was begun in 1491, whilst the second, begun in 1520, adjacent to the grotta for the antiques collection, some closets and a secret garden was on the ground floor of the Old Court of the Palazzo Ducale in Mantua.

15 The chest is a medieval piece of furniture that allowed household goods to be transported and also served as a bench, chest, container and shelf. During the fourteenth century, it became an increasingly decorated element as it was part of the dowry.

16 On other studiolî see Forino (2011: 11-12).

17 On the different models of the Wooton Patent Desk see Showalter and Dreisbach (1983).

18 Cf. Forino (2011: 75).

19 Cf. Forino (2001: 44)

20 The phrase by Thornton (1991: 135) used to indicate a type of particularly advanced four-poster bed, which appeared in Italy starting from the sixteenth century, is here referred to though in a wider meaning.

21 Tempera on wood panel, predella of the San Marco Altar-piece (San Matteo National Museum, Florence).

22 Found in the palace cellars, the alcove was later carried to the Apartment of Jole.

23 The idea of placing a bed under a construction-a sort of essential and independent small house or temple-might have ancient origins connected with religious rites or the laying out (Gr., prothesis) of the dead.

24 The furnishings of the room (c. 1814-1822) are attributed to Antonio de Simone, Giuseppe Cammarano, Gennaro Bisogno and Agostino Fondi, but the bed was probably made in France.

25 Cf. Duby (1985: 54); Régnier-Bohler (1985: 273). On the relationship between the "window as a (small) space" and intimacy, see Forino (2016b: 22-29).

26 Watercolour and black ink on paper, Museum für Angewandte Kunst, Frankfurt on Main.

27 The term Biedermeier was first used for interior decoration by Wilhelm Heinrich Riehl in 1891 to define the artists' and craftsmen's work between 1820 and 1840. Its influence has been more recently extended up to the 1848 Insurrections.

28 Cf. Le Corbusier (1954: 34). The text refers to the 11-m-long window of the house on Lake Leman, completed by the architect for his parents in 1923.

29 For the heated debate between Auguste Perret and Le Corbusier about the window, see Reichlin (1988: 59-83). 
30 In this connection also see the notes by Benjamin (1955: 108-109).

31 Furthermore, cf. Vitta (2008: 27).

32 Bachelard (1948: 134) analysed the Jonah complex with regard to the human need for a refuge in which "to regain the meditation of the original rest" that is absolute intimacy. Referring back to the myth, the philosopher maintained that the word hollow was enough to dream of a dwelling' (Ibid.: 119). On the basis of Bachelard, the myth of Jonah was reinterpreted and developed by Durand (1963: 208) and following pages.

33 In particular, see Bachelard (1957: 189) and following pages, and Durand (1963: 212) and following pages.

34 ["Small rooms and dwellings [...] sharpen the intellect, and large ones distract it"], in Solmi (1907: 31).

35 In particular, Fachinelli referred to the psychoanalytic space between patient and therapist. It should also be underlined that Durand (1963: 216) referred to the "claustrophilic delirium" concerning myths and legends of swallowing.

36 "The lived house is not an inert box: inhabited space is beyond geometric space" (Bachelard, 1957: 73).

37 Cf. Piaget and Inhelder (1947: 10 and 109-129).

38 For the phenomenology of the "interno nell'interno' in the contemporary world, see Forino (2001: 81-106).

\section{References}

Alberti L B (1432-1434) Opere volgari. Laterza: Bari, Italy, 1960. Vol. I. I Libri della Famiglia-Cena familiaris-Villa.

Arnheim R (1977) La dinamica della forma architettonica. Transl. it. Feltrinelli: Milan, 1981.

Bachelard G (1948) La terra e il riposo: Le immagini dell'intimità. Transl. it. Red: Como, 1994.

Bachelard G (1957) La poetica dello spazio. Transl. it. Dedalo: Bari, 1984.

Bachelard G (1970) Il diritto di sognare. Transl. it. Dedalo: Bari, 1993.

Baroni D (1983) I tipi di mobile. In: Wills G, Baroni D and Chiarelli B (eds). Il Mobile: Storia, progettisti, tipi e stili. Mondadori: Milan, pp 282-326.

Battisti E (1962) L'antirinascimento. Feltrinelli: Milan, vol. I.

Benjamin W (1955) Angelus Novus: Saggi e frammenti. Transl. it. Einaudi: Turin, 1995.

Benjamin W (1982) Parigi, capitale del XIX secolo: I "passages" di Parigi. Transl. it. Einaudi: Turin, 1986.

Bouroullec R and Bouroullec E (2003) Ronan and Erwan Bouroullec. Phaidon: London.

Burns H (2001) Letti visibili e invisibili nei progetti architettonici del Rinascimento. In: Scotti Tosini A (ed). Aspetti dell'abitare in Italia tra XV e XVI secolo: Distribuzione, funzione, impianti. Unicopli: Milan, pp 131-141.

Chastel A (1959) Arte e Umanesimo a Firenze, al tempo di Lorenzo il magnifico: Studi sul Rinascimento e sull'Umanesimo platonico. Transl. it. Einaudi: Turin 1964.

Cusano G (1979) La finestra e la comunicazione architettonica. Dedalo: Bari.

Davies C (2011) Il primo libro di architettura. Transl. it. Einaudi: Turin2011.

Di Domenico G (1998) L'idea di recinto: Il recinto come essenza e forma primaria dell'architettura. Officina: Rome.

Duby G (1985) Convivialità. In: Ariés P and Duby G (eds). Transl. it. La vita privata: Dal Feudalesimo al Rinascimento. Mondadori: Milan, 1993.

Durand G (1963) Le strutture antropologiche dell'immaginario: Introduzione all'Archetipologia generale. Transl. it. Dedalo: Bari, 1991.

Elias N (1936) La civiltà delle buone maniere: Le trasformazioni dei costumi nel mondo aristocratico occidentale. Il Mulino: Bologna, 2009.

Fachinelli E (1982) Claustrofilia: Saggio sull'orologio telepatico in psicoanalisi. Adelphi: Milan.

Forino I (2001) L'interno nell'interno: Una fenomenologia dell'arredamento. Alinea: Florence.

Forino I (2011) Uffici: Interni arredi oggetti. Einaudi: Turin.

Forino I (2016a) Raddoppiare il recinto. In: Visconti F and Diaconescu O (eds). I limiti dell'intervento: L'orizzonte oikologico dell'architettura. Edizioni Scientifiche Italiane: Naples, pp 58-65.

Forino I (2016b) Un'altra soglia: La finestra abitata. In: Fusco L M and Saitto V (eds). La qualità oikogena dell'architettura: Lo spazio della soglia. Edizioni Scientifiche Italiane: Naples, pp 22-29.

Foucault M (1976) La volontà di sapere: Storia della sessualità 1. Transl. it. Feltrinelli: Milan, 2011.

Franzoni C (1984) "Rimembranze d'infinite cose": Le collezioni rinascimentali di antichità. In: Settis S (ed). Memoria dell'antico nell'arte italiana. Einaudi: Turin. vol. 1, pp 301-360.

Giedion S (1948) L'era della meccanizzazione. Transl. it. Feltrinelli: Milan, 1967.

Hoffmann ETA (1822) La finestra d'angolo del cugino. Transl. it. Salerno Editrice: Rome, 1996.

Liebenwein W (1977) Studiolo: Storia e tipologia di uno spazio culturale. Transl. it. Panini: Modena, 1988.
Kahn L I (1973) La stanza, la strada e il patto umano. In: Norberg-Schulz C (ed). Louis I. Kahn: Idea e immagine. Officina: Rome. 1980, pp 137-140.

Le Corbusier. (1954) Una piccola casa. Transl. It. Biblioteca del Cenide: Cannitello, 2004.

Mumford L (1938) La cultura delle città. Transl. it. Di Comunità: Milan, 1999.

Percier C and Fontaine P F L (1801) Recueil de décorations intérieures comprenant tout ce qui a rapport a l'ameublement, comme vases, trépieds, candelabres, cassolettes, lustres, girandoles, lampes, chandeliers, cheminées, feux, poêles, pendules, tables, secrétaires, lits, canapés, fauteuils, chaises, tabourets, miroirs, ecrans, \&c., \& c., \& c; Hegon Hessiling: Paris, France.

Perrot M (2009) Storia delle camere. Transl. it. Sellerio: Palermo, Italy, 2011.

Petrarch F (1346-1366) De vita solitaria. Mondadori: Milan, Italy, 1992.

Piaget J and Inhelder B (1947) La rappresentazione dello spazio nel bambino. Transl. it. Giunti Barbèra: Florence, Italy, 1976.

Portoghesi P (1964) La biblioteca Laurenziana. In: Portoghesi P and Zevi B (eds). Michelangiolo architetto. Turin: Einaudi: Turin, Italy, pp 211-239.

Praz M (1964) La filosofia dell'arredamento: I mutamenti nel gusto della decorazione interna attraverso i secoli dall'antica Roma ai nostri tempiLonganesi \& C.; Milan, Italy, 1990.

Régnier-Bohler D (1985) Esplorazione di una letteratura. In: Ariés P and Duby G (eds). Transl. it. La vita privata: Dal Feudalesimo al Rinascimento. Mondadori: Milan, Italy, 1993, vol. II.

Rewald S (2011) Rooms with a View: The Open Window in the 19th Century. The Metropolitan Museum of Art: New York, New Haven, CT; London, Yale U.P.

Reichlin B (1988) "Une petite maison" sul lago Lemano: La controversia Perret-Le Corbusier. Lotus International; 60, 59-83.

Semper G (1851) I 4 elementi dell'architettura. In: Quitzsch H (1962) La visione estetica di Semper. Transl. it. Jaca Book: Milan, Italy. 1991, pp 169-238.

Semper G (1879-1889) Lo stile, nelle arti tecniche e tettoniche o estetica pratica: Manuale per tecnici, artisti e amatori. Transl. it. Laterza: Rome-Bari, Italy, 1992

Showalter C and Dreisbach J (1983) Wooton Patent Desks: A Place for Everything and Everything in Its Place. Indiana U. P.: Bloomington, IL.

Solmi E (1907) Leonardo (1452-1519). G. Barbera: Florence, Italy.

Solmi E (1910) La resurrezione dell'opera di Leonardo. In: Società Leonardo da Vinci di Firenze (ed). Leonardo da Vinci: Conferenze fiorentine. Treves: Milan, Italy, pp 3-48.

Sozzi L (2011) Gli spazi dell'anima: Immagini di interiorità nella cultura occidentale. Bollati Boringhieri: Turin, Italy.

Teyssot G (2013) A Topology of Everyday Constellations. The MIT Press: Cambridge, MA, London.

Thornton D (1997) The Scholar in His Study: Ownership and Experience in Renaissance Italy. Yale U.P.: New Haven, CT, London.

Thornton P (1984) Il gusto della casa: Storia per immagini dell'arredamento, 1620 1920. Transl. it. Mondadori: Milan, Italy, 1985.

Thornton P (1991) Interni del Rinascimento Italiano, 1400-1660Transl. it. Leonardo: Milan, Italy, 1992.

Venturi R (1966) Complessità e contraddizione in architettura. Transl. it. Dedalo: Bari, Italy, 1980.

Vitta M (2008) Dell'abitare: Corpi spazi oggetti immagini. Einaudi: Turin, Italy.

Zevi B (1948) Saper vedere l'architettura: Saggio sull'interpretazione spaziale dell'architettura. Einaudi: Turin, Italy, 1991.

\section{Data availability}

Data sharing not applicable to this article as no datasets were generated or analysed during the current study.

\section{Acknowledgements}

The author acknowledges the language translation support of Roanna Weiss and Richard Sadleir (Language Password SaS).

\section{Additional information}

Competing interests: The author declares that there are no competing interests.

Reprints and permission information is available at http://www.palgrave-journals.com/ pal/authors/rights_and_permissions.html

How to cite this article: Forino I (2017) The interno nell'interno: some furnishing paradigms for an interior as interiority. Palgrave Communications. 3:17022 doi: 10.1057/ palcomms.2017.22.

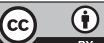

This work is licensed under a Creative Commons Attribution 4.0 International License. The images or other third party material in this article are included in the article's Creative Commons license, unless indicated otherwise in the credit line; if the material is not included under the Creative Commons license, users will need to obtain permission from the license holder to reproduce the material. To view a copy of this license, visit http://creativecommons.org/licenses/by/4.0/ 